\title{
Research on Evaluation System of Personnel Training Mode for Chinese Foreign Policing Management Major
}

\author{
Yuchi Zhu ${ }^{1,}$, Liang $\mathrm{Hu}^{1, \mathrm{~b}}$ \\ ${ }^{1}$ Department of Humanities and Management, JiangXi Police College, NanChang City, JiangXi \\ Province, P.R.China \\ a447058887@qq.com, bhuliang_thu@163.com
}

Keywords: evaluation system; personnel training mode; foreign policing management

\begin{abstract}
According to the new requirements for China's current foreign policing management work, this paper makes the undergraduate students in public security colleges as the object of study, research related to policing talents training evaluation criteria, principles and elements and proposed an evaluation index system for the foreign police professional talent training model.
\end{abstract}

\section{Introduction}

Foreign professional policing is a new subject, with the rapid development of the world politics, economy, science and technology, the connection between the Chinese police and national police are more widely, to reform the traditional teaching system of policing, innovation of traditional policing professional setting, enhance quality of traditional materials, culture students' innovation ability and the ability of information technology, the construction of a new foreign police personnel training mode, has become the current public security organs is one of the focuses of the research topic ${ }^{[1][2][3]}$.

Personnel training mode evaluation research has a lot of, but foreign police professional talent training evaluation model is less, only to build complete forestry economy and management professional personnel training quality evaluation index system to for professional talent training quality model to make a clear judgment, and can judge clearly the focus of professional personnel training $^{[4][5]}$. Therefore, the public security college students as the research object, a model of quality evaluation index system of training of foreign police talents.

\section{Construction of evaluation index system}

For a particular subject and talent training quality evaluation index system construction should set up some of the indicators for and easy to operate, as far as possible by measuring the students in all aspects of quality evaluation of the quality of training mode. The evaluation index system is divided into three layers: the first layer is the target layer, namely, talent cultivation quality evaluation results; the second level indicators, including study, work, life, development potential, evaluation on employers; the third layer as the secondary index, select representative to reflect the foreign police professional talent training mode quality characteristics. In this paper, the evaluation index system of the training mode of foreign police professional talents is shown in Figure 1. 


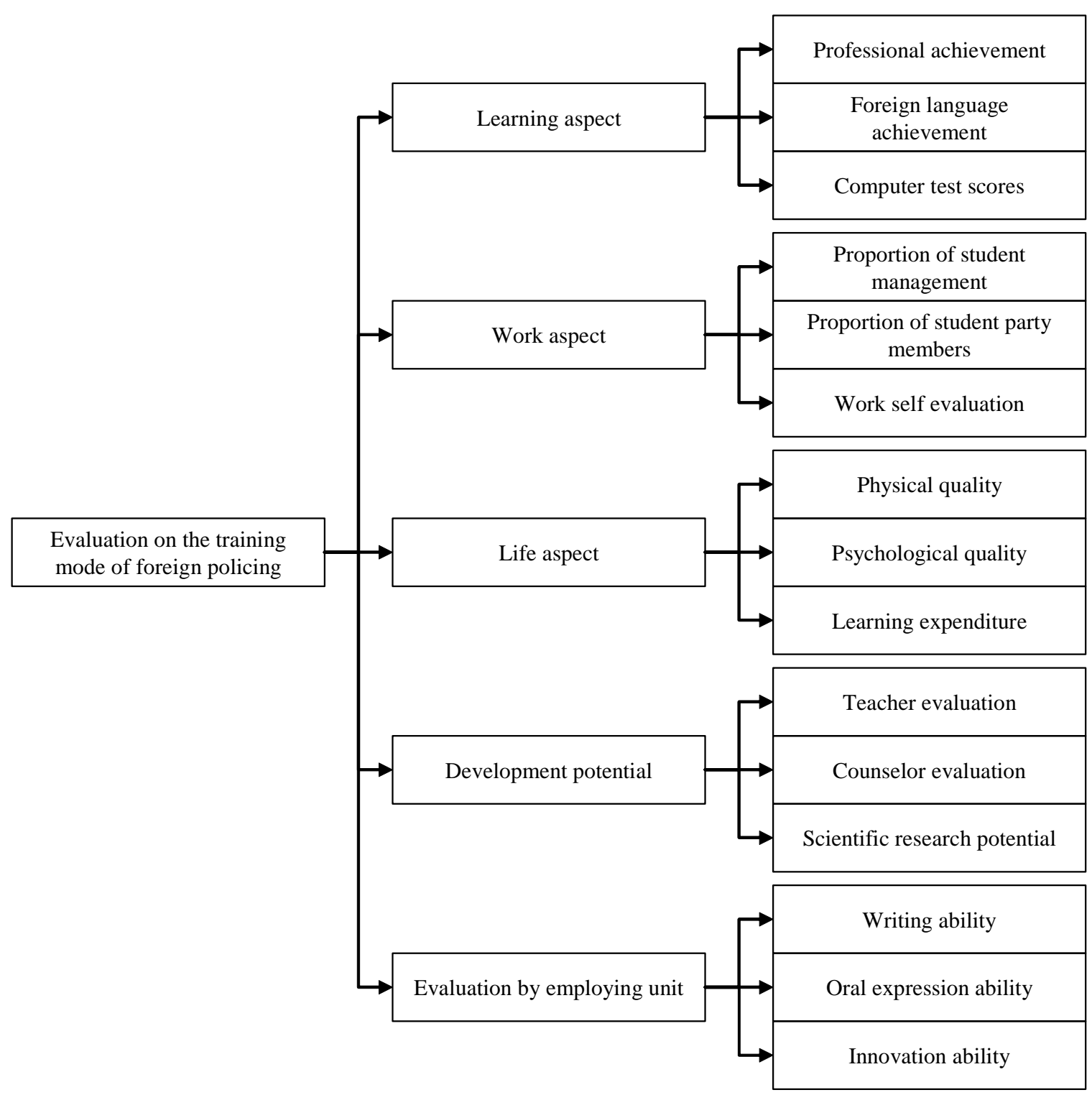

Fig.1 Evaluation index system of personnel training mode of foreign policing management

\section{Standard of evaluation index weight}

In this paper, the analytic hierarchy process is used to determine the weight of evaluation indexes at all levels. First, construct a level indicators of foreign policing management professional personnel training mode quality influence degree of judgment matrix and the secondary index influence on one class index judgment matrix, to index between the importance as judged by comparison, calculate the weight of indicators at all levels.

Table 1 Standard degree of the judgment matrix

\begin{tabular}{|c|l|}
\hline Value & \multicolumn{1}{|c|}{ Note } \\
\hline 1 & Two indicators compared to the same degree of importance \\
\hline 3 & Two indicators compared to an indicator is a little more important than another \\
\hline 5 & Two indicators compared to an indicator is significantly more important than another \\
\hline 7 & Two indicators compared to an indicator is very important than another \\
\hline 9 & Two indicators, an indicator than the other indicators of extreme importance \\
\hline
\end{tabular}

The elements of vector $\mathrm{A}$ by adding get vector $\mathrm{W}$, then the normalized vector $\mathrm{W}$ is obtained the relative weight $w$ of each index, and finally the relative weight $w$ of each index and the index corresponding to the higher index of multiplying the weights, to get the absolute weight $w$. Vector A follows the formula: 


$$
A=\frac{a_{i j}}{\sum a_{i j}}
$$

\section{Result and analysis of index weight}

According to the above measures, the weight of each index in the quality evaluation index system of the professional training mode of police professional talents is obtained. From Table 2, the evaluation index system of the training mode of the foreign affairs police professional personnel, the weight of innovation ability is the highest, followed by the scientific research ability. Therefore, the personnel training mode of the foreign affairs police profession should pay more attention to the training of the innovation ability.

Table 2 Weight of evaluation index of training mode of foreign policing personnel

\begin{tabular}{|c|c|c|c|c|}
\hline Target layer & First level index & $\begin{array}{c}\text { Total } \\
\text { weight }\end{array}$ & Second level index & $\begin{array}{l}\text { Absolute } \\
\text { weight }\end{array}$ \\
\hline \multirow{15}{*}{$\begin{array}{l}\text { Evaluation on the } \\
\text { training mode of } \\
\text { foreign policing }\end{array}$} & \multirow[t]{3}{*}{ Learning aspect } & \multirow[t]{3}{*}{0.1429} & Professional achievement & 0.0771 \\
\hline & & & Foreign language achievement & 0.0425 \\
\hline & & & Computer test scores & 0.0234 \\
\hline & \multirow[t]{3}{*}{ Work aspect } & \multirow[t]{3}{*}{0.1429} & $\begin{array}{llr}\begin{array}{l}\text { Proportion } \\
\text { management }\end{array} & \text { of student } \\
\end{array}$ & 0.0317 \\
\hline & & & $\begin{array}{l}\text { Proportion of student party } \\
\text { members }\end{array}$ & 0.0317 \\
\hline & & & Work self evaluation & 0.0794 \\
\hline & \multirow[t]{3}{*}{ Life aspect } & \multirow[t]{3}{*}{0.1429} & Physical quality & 0.0612 \\
\hline & & & Psychological quality & 0.0612 \\
\hline & & & Learning expenditure & 0.0204 \\
\hline & \multirow[t]{3}{*}{ Development potential } & \multirow[t]{3}{*}{0.2857} & Teacher evaluation & 0.1052 \\
\hline & & & Counselor evaluation & 0.0552 \\
\hline & & & Scientific research potential & 0.1253 \\
\hline & \multirow{3}{*}{$\begin{array}{l}\text { Evaluation } \\
\text { employing unit }\end{array}$} & \multirow[t]{3}{*}{0.2857} & Writing ability & 0.0850 \\
\hline & & & Oral expression ability & 0.0850 \\
\hline & & & Innovation ability & 0.1257 \\
\hline
\end{tabular}

\section{Discussion and future work}

Construction of the evaluation index system of the training mode of foreign affairs professional talents can reflect the influence degree of each factor on the quality of personnel training in the professional training mode. The research shows that the innovation ability is the most important for the training mode of the foreign affairs police professional talents, and the second is the ability of scientific research.

Therefore, first of all, the school should let students more involved in the teaching activities, increase students for the interest in the study of the subject, for the students' thinking of independent innovation to provide inspiration, to enable students to have different points of view, and mutual exchanges and discussions.

Second, the subject examination should be more open to the topic of the form, so that students can fully express their views, but also to allow teachers to understand the students' thinking ability.

Finally, to increase the social practice opportunities for students to do more closely, so that students can do theory with practice. 


\section{Acknowledgements}

This author's work is supported by JiangXi Research on teaching reform of higher education(JXJG-14-19-1, JXJG-15-19-3), JiangXi Science and technology research project of Education Department(GJJ151193) , JiangXi Social Science Planning Projects during the 12th Five-Year Plan(14TQ05) and JiangXi Police College Scientific Research Project(2014QN001).

\section{References}

[1] Di Min. The establishment of consumer oriented college personnel training evaluation system [J]. Science and technology management, 2002, (1): 88-86. (in Chinese)

[2] Zhao Tie. Personnel training social evaluation of the quality of construction [J]. Higher education forum, 2004, (3): 146-149. (in Chinese)

[3] Zhang Li. China's talent evaluation index about the elements [J]. Inner Mongolia statistics, 2005, (2): 8-9. (in Chinese)

[4] Li Mei. Colleges and universities mechanical talent quality evaluation and countermeasure analysis based on the AHP [D]. Hangzhou: Zhejiang University of Technology, 2006. (in Chinese)

[5] Li Guanghong. Research on the evaluation index system of high level talents [J]. Science and technology progress and countermeasures, 2007, (4): 189-186. (in Chinese)

[6] Yin Zhongkai. Construction of evaluation system for innovative talents cultivation [J]. Journal of Liaoning Technical University: Social Science Edition, 2008, (6): 658-655. (in Chinese)

[7] Wu Qingwen. Research on evaluation index system of research universities from the perspective of structural benefit [J]. Academic exchange, 2009, (4): 186-191. (in Chinese)

[8] Li Baozhu. Research on the evaluation index system of logistics talents based on ANP [J]. Journal of Tianjin University of Technology, 2009, (4): 77-74. (in Chinese)

[9] Li Junli. Research on the direction of talents cultivation in agricultural and forestry economics and management [J]. Tropical agricultural science, 2011, 31 (4): 89-91. (in Chinese)

[10] Hong Meixiang. Tourism talents based on AHP training quality evaluation system of construction [J]. Economic research Herald, 2011, (3): 173-174. (in Chinese) 